\title{
Hepatitis $C$ viral clearance in an intravenous drug-using cohort in the Dublin area
}

\section{ABSTRACT}

Background The rate of spontaneous HCV viral clearance is reported as 20-25\% but recent data indicate a higher frequency in some cohorts. The rate of spontaneous clearance in intravenous drug users has not been reported in an Irish setting.

Aims To determine the rate of spontaneous hepatitis $\mathrm{C}$ viral clearance and genotype in an Irish intravenous drug-using cohort.

Methods Drug users attending five drug treatment clinics in the Dublin were investigated. Data were prospectively recorded from January 1997 to June 2001 and follow-up testing completed in 2003. There were 496 HCV antibody positive patients identified and assessed for HCV RNA clearance. All were HIV and hepatitis B negative, $68.8 \%$ were male.

Results HCV RNA negativity (viral clearance) was documented in $38 \%$ of patients. Viral clearance was $47.4 \%$ in females and $34.5 \%$ in males $(p=000.6)$. Clearance was independent of age or duration of intravenous drug use. Viral clearance as defined as two negative consecutive HCV RNA tests, a minimum of one year apart, was sustained in $82.2 \%$ at twoyear follow-up, giving an overall viral clearance of $31.1 \%$. HCV genotype 1 and 3 were most commonly identified at $48.8 \%$ and $48.5 \%$ respectively in those with chronic infection.

Conclusions Spontaneous HCV viral clearance occurs at a higher frequency than previously reported. Genotype 1 and 3 are commonest in the patient cohort.

\section{Keating, 5 Coughlan $^{1}$, J Connell, BSweeney, EKeen an}

The Drug Treatment Centre Board, Trinity Court, Pearse Street, Dublin 2; National Virus Reference Laboratory', University College Dublin, Belfield, Dublin 4

\section{INTRODUCTION}

In the past decade, hepatitis $C$ has been identified as the major cause of non-A, non$B$ hepatitis in the developed world. ${ }^{3}$ Risk factors include intravenous drug use with needle sharing, exposure to contaminated blood or blood products, high-risk sexual contact or household contact and low socio-economic status. ${ }^{49}$ Acute infection is frequently sub-clinical or asymptomatic but chronic infection can lead to cirrhosis and hepatocellular carcinoma. ${ }^{9 "}$

Disease progression has been linked to excess alcohol consumption, duration of intravenous drug use, older age at infection and co-infection with other viruses. ${ }^{12}$ At least six different genotypes and more than 90 subtypes of hepatitis $\mathrm{C}$ exist worldwide. ${ }^{\prime 3}$ Disease outcome and treatment response 
may differ according to genotype thus genotyping is warranted among patients who are being considered for treatment.

Currently, third-generation enzyme immunoassays (EIA-2 and EIA-3) for hepatitis $\mathrm{C}$ antibody (anti-HCV) are the most widely used screening tests for the diagnosis of HCV infection, confirmed by recombinant immounoblot assay (RIBA). ${ }^{3}$ These tests however do not distinguish between acute, chronic or resolved infection. In the event of a positive antibody test, confirmatory testing of HCV RNA in serum by polymerase chain reaction $(P C R)$ is seen as the gold standard for the diagnosis of active $\mathrm{HCV}$ infection. ${ }^{14}$

In Ireland, two main patient cohorts who have been exposed to hepatitis $C$ have been identified. The first group are recipients of blood or blood products contaminated with hepatitis $\mathrm{C}$ between 1970 and 1994 . $^{8}{ }^{9}$ The second group are intravenous drug users (IVDUs). Retrospective analysis has shown that the overall seroprevalence for hepatitis $C$ in this group is $52-81$ per cent. ${ }^{5}{ }^{15}$

In the greater Dublin area there are an estimated 13,000 intravenous drug users, the majority of whom are in treatment in the HIV and addiction services. ${ }^{16}$ Once attending these clinics, all IVDUs are actively encouraged to avail themselves of viral testing for hepatitis $A$, hepatitis $B$, hepatitis $C$ and HIV and vaccination against hepatitis $A$ and B, where appropriate. In 1997, designated hepatitis $C$ review clinics were introduced in the main drug treatment units in the city to offer drug-using clients HCV RNA testing and assessment of their drug stability and alcohol consumption. This report highlights preliminary data from these hepatitis $C$ review clinics seven years after their inception.

\section{METHODS}

Data were prospectively recorded on the 496 hepatitis $C$ antibody positive patients who presented for hepatitis $C$ testing in the drug treatment clinics in the Dublin area from January 1997 to June 2001. Referrals to the clinics were made by psychiatrists and general practitioners specialising in drug abuse and were independent of clinical fitness or drug stability. Patients had not seroconverted for hepatitis B or HIV as confirmed by serological testing.

For each patient, the following data were obtained: age, sex and year of commencement of intravenous drug use. HCV RNA status was recorded for each patient by the Roche Amplicor HCV polymerase chain reaction method with a laboratory assay cutoff of 100 copies/ml. ${ }^{178}$ HCV genotyping was performed by restriction-fragment-length polymorphism analysis of sequences in the $5^{\prime}$ non-coding region of Hepatitis $\mathrm{C}$ genome..$^{7,8}$

Comparative statistics were performed using Chi squared test and Levene's test for equality of variances.

\section{RESULTS}

\section{Demographic Data}

Of those who participated in this study, $68.8 \%$ were male and $31.2 \%$ were female. Mean ages were 28.75 (SD 6.35) for males and 26.11 (SD 5.93) for females (ns). Mean ages of IVDU initiation for males and females were 20.20 (SD 4.74) and 20.27 ( ${ }^{\text {SD }} 4-43$ ) respectively (ns). Average duration of IVDU was 9.23 (SD • 5.93) for males and 6.59 (SD 5.72) for females $(p<0.001)$.

\section{Viral Data}

Of the 496 anti HCV-positive participants in this study, HCV RNA was not detected in 191. This results in an initial viral clearance rate of $38.4 \%$. Sustained viral clearance rate was $31.1 \%$. HCV RNA clearance was more frequent in females than males $X^{2}=746, D F i, p=0.006$ (Table 1). Mean age in the HCV RNA positive group was 27.7 (SD 6.3) and 27.8 (SD 6.4) in the HCV negative group $(\mathrm{t}=0.04, \mathrm{p}=0.97)$. Those who gave a history of jaundice were more likely to clear the virus spontaneously $(12.04 \%)$ than those who did not clear the virus $(7.87 \%) X^{2}=6.77$ DFi, $p=0.006$. Viral clearance was not associated with duration of intravenous drug use (Table 1). 
Of the 299 PCR positive samples in which genotyping data was available (98\%), genotype I was observed in 146 (48.8\%), genotype 2 in 6 (2.\%), genotype 3 in 145(48.5\%) and genotype 4 in $2(0.7 \%)$. Genotypes 5 and 6 were not identified in this patient cohort. Measurement of genotype I or 3 was independent of sex (Table 2).

Viral clearance data at two-year follow-up showed that of a total of $127(66.5 \%)$ originally PCR negative patients who were retested, 21 (17.2\%) were now PCR positive.

\section{DISCUSSION}

In this study of IVDUs in the Dublin area, thirty eight per cent of clients had no evidence of hepatitis $C$ virus as assessed by PCR assay. Viral clearance was commoner in females and in those with a history of jaundice at diagnosis but was independent of length of time since initial intravenous drug use. In those who were PCR positive, genotypes 1 and 3 were most commonly noted.

Villano et al have reported a 14 per cent level of viral clearance in a cohort of 43 people with a history of illicit drug use whom they followed over an eight-year period. ${ }^{19}$ Viral clearance was more likely to be associated with ancestry and a history of jaundice. ${ }^{19}$ Similar data have also been reported in the U.S.A. ${ }^{20}$ In a study of 258 patients, viral clearance was observed in 17 per cent of IVDUs. A history of parenteral exposure and a long drug-free interval were both associated with an increased likelihood of persistent viraemia. In a further study of 13 hepatitis C positive IVDUs, apparent viral clearance was observed in 38 per cent. ${ }^{21}$ In an Irish study of a large cohort of women who tested positive for hepatitis $C$ following contaminated anti-D immune globulin, a viral clearance rate of 45 per cent was reported. ${ }^{9}$

In this study, viral clearance, as demonstrated by the percentage of PCR-negative samples
Table 1

CHARACTERISTICS OF PARTICIPANTS ACCORDING TO PATTERN OF VIRAEMIA

\begin{tabular}{cccc}
\hline Characteristic & $\begin{array}{c}\text { Viral Clearance } \\
(n=191)\end{array}$ & $\begin{array}{c}\text { Viral persistence } \\
(n=305)\end{array}$ \\
\hline
\end{tabular}

Sex, $n(\%)$

$\begin{array}{lrr}\text { Male } & 118(34-5 \%) & 224(65.5 \%) \\ \text { female } & 73(474 \%) & 81(52.6 \%)\end{array}$

Mean age (SD) at

time of initial

HCV RNA testing

$27.8(6.4)$

27.7(6.3)

NS

Duration of IVDU

In years $(S D)$

$8.8(6.4) \quad 8.6(5.9)$

NS

TABLE 2

CHARACTERISTICS OF PARTICIPANTS ACCORDING TO PATTERN OF VIRAEMIA

\begin{tabular}{lrrr}
\hline Genotype & $\begin{array}{r}\text { Male } \\
(\mathbf{n = 2 1 9 )}\end{array}$ & $\begin{array}{c}\text { Female } \\
(\mathbf{n = 8 0})\end{array}$ & P \\
\hline Type i, n (\%) & $108(49.6 \%)$ & $38(475 \%)$ & NS \\
Type 2, n (\%) & $5(2.0 \%)$ & $1(1.2 \%)^{\wedge}$ & * \\
Type 3, n (\%) & $105(47.9 \%)$ & $40(50.0 \%)$ & NS \\
Type 4, n (\%) & $1(0.5 \%)$ & $1(1.2 \%)$ & *
\end{tabular}

* Sample size too small for statistical analysis

in this cohort is also high at $38 \%$. Sustained viral clearance was also high at $31.1 \%$. It was not possile to elicit whether the drop in viral clearance represented reinfection or reactivation. There was no clinical bias at referral level in that all patients, irrespective of clinical well-being, were reviewed. We included all patients who were hepatitis $C$ positive, as selecting only patients who were unwell due to HCV infection may have biased the overall viral clearence rate, as may be the case in hospital based Hepatitis $\mathrm{C}$ clinic audits. Female 
patients had significantly higher levels of viral clearance than male patients. A similar finding was reported by Farrell and from a study of intravenous drug users in Iceland but a contrasting finding was reported in the Dionysos study, which noted that HCV RNA positivity was higher in females. ${ }^{22,24}$ Viral clearance in this study was higher in those with a history of jaundice at seroconversion, as was previously noted by Villano et al. ${ }^{19}$ Viral clearance was independent of duration of intravenous drug use both for males and females. This is in contrast with the findings of Quinn et al in which an association between persistent viraemia and time since most recent parenteral exposure was noted. ${ }^{20}$

Many immunological mechanisms of HCV viral clearance have been postulated. IL-io haplotypes, HCV specific T-cell responses and tumour necrosis factor alpha gene polymorphism have all been implicated. ${ }^{2527}$ Immune function may be altered in this IVDU cohort but a review of this is beyond the scope of this study.

Genotypes I and 3 diseases were the most common forms of hepatitis $C$ identified in this cohort. It has been suggested that spontaneous clearance of hepatitis $\mathrm{C}$ might be higher in patients with genotype 3 disease than genotype i. ${ }^{28}$ Genotype data at seroconversion were not available in this cohort.

Genotype data would suggest that there is marked geographic variability. In the United States, approximately 70 per cent of hepatitis C-infected persons are infected with genotype i. ${ }^{29}$ In England and Wales, hepatitis $C$ genotypes 1 and 3 are the most prevalent genotypes in intravenous drugabusing patients. ${ }^{30} \mathrm{~A}$ similar genotype pattern was found in Italy, Germany, Iceland and Spain. ${ }^{\wedge ! \wedge}$ Inthis Irish group, genotypes $i$ and 3 accounted for the majority of cases, accounting for $48.8 \%$ and $48.5 \%$ IVDU patient cohort infected with hepatitis respectively. Genotypes were independent of sex.
In summary, we report a high rate of viral clearance in a Dublin intravenous drug-using cohort attending drug services for treatment. The cohort size was large and reflected the Dublin drug community in terms of the percentage of male to female, the large age range and durations of intravenous drug use. In contrast to many published reports from similar communities in Europe, the rate of viral clearance was found to be higher in females than males and independent of age and duration of intravenous drug use.

\section{REFERENCES}

1. Choo QL, Kuo G, Weiner AJ, Overby LR, Bradley DW, Houghton M. Isolation of a cDNA clone derived from blood-borne non-A, non-B viral hepatitis genome. Science ig89;224:359-62

2. Alter MJ, Hadler SC. Judson FN et al. Risk factors for acute non-A, non-B hepatitis in the United States and association with hepatitis $C$ infection. JAMA 1990:264:2231-2235.

3. Alter MJ, Margolis HS, Krawczynski K et al. The natural history of community-acquired hepatitis C in the United States. N EnglJMed 1992:327:1899-1905.

4. Alter MJ. Epidemiology of hepatitis C. Hepatologyiggj;26:62S-sS.

5. Smyth B, Keenan E, O'Connor J. Evaluation of the impact of Dublin's expanded harm reduction programme on prevalence of hepatitis $\mathrm{C}$ among short-term injecting drug users. J Epidemiol Comm Health 1999;53:434-435

6. Villano SA, Vlahov D, Nelson KE, Lyles CM, Cohn S, Thomas DL Incidence and risk factors for hepatitis $\mathrm{C}$ among injection drug users in Baltimore, Maryland J Clin Microbiol 1997:35:3274-7.

7. Tong MJ, EL-Farra NS, Reikes AR, Co RL. Clinical outcomes after transfusion-associated hepatitis C. N EnglJ Med 1995:332:1163-6.

8. Murphy EL, Bryzman SM, Clynn SA et al. Risk factors for hepatitis C infection in United States blood donors. Hepatology 200031756-762.

9. Kenny-Walsh E. Clinical outcomes after hepatitis C infection from contaminated anti-D immune globulin. N EnglJ Med 1999:340:1228-33. 
10. Seeff LB, Buskell-Bales Z, Wright EC et al. Long-term mortality after transfusionassociated non-A, non-B hepatitis. N EnglJ Med 1992327:1906-11.

11. Fattovich C, Ciustina G, Degos F et al. Morbidity and mortality in compensated cirrhosis type $\mathrm{G}$ a retrospective follow-up study of 384 patients. Gastroenterol 1997:112:46372.

12. Neiderau C, Lange S, Heintges T et al. Prognosis of chronic hepatitis C: results of a large, prospective cohort study. Hepatology 1998; 6;1687-95.

13. Bukh J, Miller RH, Purcell RH. Genetic heterogeneity of hepatitis $C$ virus: quasispecies and genotypes (review).Semin Liver Dis 1995:15:41-63

14. Lok AS, Gunaratnam NT. Diagnosis of hepatitis C. Hepatology 1997;26(3 suppl i):48S-56S.

15. Allwright $\mathrm{S}$, Bradley $\mathrm{F}$, Long $\mathrm{J}$ et al. Prevalence of antibodies to hepatitis B, Hepatitis C and HIV among Irish prisoners: results of a national cross sectional survey. BMJ 200032178

16. Comiskey CM, Barry JM. A capture-recapture study of the prevalence and implications of opiate use in Dublin. EurJ Public Health 2001 Jun;1i(2):198-2OO.

17. Chan SW, McOmish S, Holmes EL et al. Analysis of a new hepatitis $C$ virus type and its phylogenetic relationship to existing varients. J Cen Virol 1992:73:1131-40.

18. Simmonds P. Typing of HCV: a comparison of PCR-based and serological methods. Mol Diagn i993;i(5):4-5-

19. Villano SA, Vlahov D, Nelson KE.Cohn S, Thomas DL Persistence of viremia and the importance of long-term follow-up after acute hepatitis C infection. Hepatology 19993:908-14.

20. Quinn PGJamal MM, Carey JDetal. A casecontrol study of the factors associated with spontaneous resolution of hepatitis $C$ viremia. Am J Gastroenterol 19993:668-73

21. BeldM, Penning M,van Putten Metal. Quantitative antibody responses to structural (core) and nonstructural (NS3, NS4 and NS5) hepatitis $C$ virus proteins among seroconverting injecting drug users: impact of epitope variation and relationship to detection of HCV RNA in blood. Hepatology 1999:4:1288-98.
22. Farrell G. 'Hepatitis $C$ liver disorders and liver health', MacLennan and Petty, Sydney, Philadelphia, London, 2002.

23. Love A, Sigurdson JR, Stanzeit B et al. Characteristics of hepatitis $C$ virus among intravenous drug users in Iceland. Am J Epidemiol 1996; 143:631-6.

24. Ballentani S, Pozzato G, Saccoccio G et al. Clinical course and risk factors for hepatitis $C$ virus related liver disease in the general population: report from the Dionysos study. Gut 1999:44:874-80.

25. Mangia A, Santora R, Piattelli M et al. ILio haplotypes as possible predictors of spontaneous clearance of HCV infection. Cytokine 2004; 19:331-7

26. Lehmann M, Meyer MF, Monazahian M et al. High rate of spontaneous clearance of acute hepatitis $\mathrm{C}$ genotype 3 infection. J Med Virol 2004:73387-91.

27 Lau JY, Mizokami M, Kolberg JA et al. Application of six hepatitis $C$ genotyping systems to sera from chronic hepatitis $C$ patient in the United States../ Infect Dis 1995:171:281-9.

28. Harris KA, Gilham C, Mortimer PPJeo CG. The most prevalent hepatitis $C$ genotypes in England and Wales are $3 \mathrm{a}$ and la.JMed Virol 1999:58:127-31

29. Alonso P, Orduna A, San Miguel A et al. Variants of hepatitis $C$ virus in different risk groups. Comparative study of a method for genotyping and another for serotyping. Enferm Infecc Microbiol Clin 1998:16:111-7

30. Berg T, Hopf U, Stark K et al. Distribution of hepatitis $C$ virus genotypes in German patients with chronic hepatitis C: correlation with clinical and virological parameters. J Hepatol 1997:26:484-91.

31. Alonso-Alonso P, Orduna A, San-Miguel A et al. Genotypes of hepatitis C virus: their relationship with risk factors, the severity of liver disease and the serologic response. Med Clin Bare 1998:110:681-6.

Correspondence to: Dr. 5 Keating, The Drug Treatment Centre Board, Trinity Court, 30/31 Pearse Street, Dublin 2. 